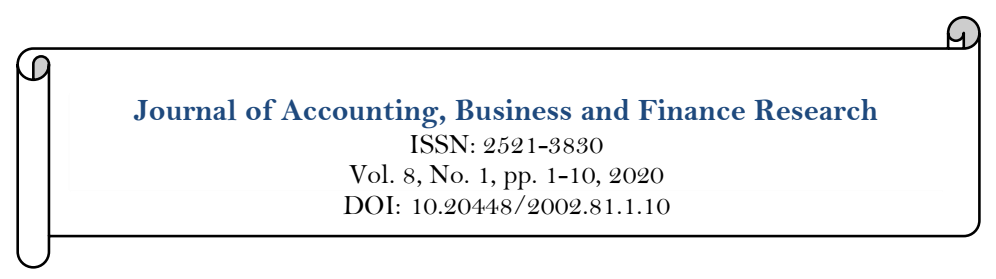

\title{
Does Ownership Structure Affect Risk Management? Evidence from an Emerging Economy, Kenya
}

\author{
Thomas Kiptanui Tarus ${ }^{*}$ \\ Joel K Tenai ${ }^{2}$ \\ Joyce Komen ${ }^{3}$ \\ ${ }^{1,2}$ Department of Accounting and Finance, Moi University, Kenya. \\ 'Email:tarus9116@gmail.com \\ ${ }^{s}$ Department of Management Science, Moi University, Kenya.
}

\section{Abstract}

The purpose of the research is to establish the impact of ownership structure on risk management among listed non-financial firms in the Nairobi Securities Exchange, Kenya. The panel research design was appropriate and the population comprised of all 67 listed firms. Based on the inclusionexclusion criterion, 41 non-financial firms were chosen from 2010-2017 while data was analyzed using logistic regression. The statistical values revealed that $(\beta=0.297, p<0.05)$ ownership structure significantly and positively impacts risk management. The structure of owners in relation to shareholdings is more likely to play an essential part in hedging transactions as it improves the worth of their equities which translates to enhanced efficiency and thus maximizing their wealth. The study contributes to understanding the structure of ownership and risk management via the utilization of hedging tools to alleviate exposure levels.
Keywords:

Ozonership structure

Risk management

Corporate governance

Agency theory

Stakeholders' theory.

JEL Classification:

G3.

Licensed:

This work is licensed under a

Creative Commons Attribution 4.0

License.

Publisher:

Scientific Publishing Institute

Accepted: 19 November 2019

Published: 4 December 2019

Funding: This study received no specific financial support.

Competing Interests: The authors declare that they have no competing interests.

\section{Introduction}

The approach to the management of risk in the contemporary economy has so far been the most influential phenomena both theoretically as well as empirical studies. This philosophy builds on the classical Modigliani-Miller paradigm (Modigliani \& Miller, 1958) which sets out the circumstances for the inappropriateness of financial structure for corporate worth. Subsequently, the paradigm was expanded to the field of risk management, which stipulates the hedging operations of companies. Studies revealed that management of risk is not about constant reduction of entities risks, but how companies select the degree and the magnitude of exposures that suit their core objective (Crouhy, Galai, \& Mark, 2006). This implies that prosperous firms take risk and manage in relation to the return. By relaxing Modigliani's assumptions and allowing capital market imperfections in the economy, Smith and Stulz (1985) provided justification as to why businesses may opt to hedge by using derivatives tools used in this study as a proxy for managing hazards. The theory advocate that businesses with high exposure levels with respect to interest rate hazards, commodity prices, and foreign exchange rates ought to use hedging tools so as to moderate the levels of exposures while also improving the worth of the firm which in turn maximizes the shareholder's value. 
In an uncertain investment world, management of risks has developed to be a key component of the firm's business policy. Several academicians in the field of finance have labeled risk management differently, but all agree that the capacity to handle risk will help businesses to behave more confidently on future company choices. In the words of Cumming and Hirtle (2001) management of risk relates to the overall manner followed by businesses in outlining the company's program, ascertaining the risks to which they are imperiled, estimating and monitoring the magnitude of the hazards they encounter. According to Hull (2012) management of risk relates to the practice of generating monetary worth in the establishment by applying hedging instruments in handling exposures under the uncertain business environment. In this respect, it is concluded that an operational risk management structure guides the company in achieving its objectives, improving accounting standards and preserving its brand image.

The finance theory points out that the management goals of the contractual agreement are to exploit the market worth of shareholders' securities by investing in an environment where the returns are not certain. The necessity for managing exposures in alleviating the extent of risk levels is by devising risk management approaches in line with the general business objective of maximizing shareholder's worth. The management of risk, therefore, encompasses the utilization of hedging tools such as futures contracts, forward contracts, option agreements, commodity derivatives and swaps to curb the uncertainty of an entity (Rao, 2012). According to Leung and Horwitz (2010) strong governance concerns support local and international companies in attracting low-cost capital investment via enhanced investor and creditor trust. This implies that companies that are governed appropriately are well supported by deep and transparent financial markets, robust legal structures, and efficient resource distribution. This, in turn, permits financial and economic stability in improving domestic and international growth rates, while poorly regulated firms do the inverse.

In recent years, hedging contracts have increased significantly due to globalization and as a result, it has widely been used by local and multinational entities to cushion against severe perils. In this respect, financial derivatives utilization is not about the elimination of risk, but it is about managing hazards by selectively choosing those risks that the organization is contented with and minimizing those not comfortable with Rao (2012). This, therefore, means that the financial hedging tools serve a useful purpose in attaining the goals of entities risk by shrinking unwanted portions of exposures. In corporate finance, when a company narrows its risk exposure by using trading derivatives, it is said to be hedged and by doing so mitigating the hazards of a company by one or more operations in capital markets (Paunović, 2014). According to Hentschel and Kothari (2001) hedging relates to a risk management activity that utilizes financial derivatives tools in alleviating the adverse effects of the exchange rate, interest rate, and commodity price volatility in the business environment. Other scholars such as Mittal, Khakhar, and Mittal (2015) denote hedging as a risk management strategy used to compensate for the likelihood of losses triggered by fluctuations in commodity, currency or securities prices. These, therefore, indicate that companies extensively employ hedging against activities to reduce the degree of exposures.

Existing risk management theories by Stulz (1996) suggest that the foremost objective of risk management is to eliminate the likelihood of expensive lower-size results that would cause financial distress or render a business unable to implement the investment portfolio. Furthermore, analysis done by Aaron (1995) of US companies on the degree to which organizations use derivatives to manage risk revealed that 63.2 percent of the sample firms were using hedging tools to manage exposures levels. In addition, Grant and Marshall (1997) surveyed large UK firms between the years 1994 and the year 1995. The statistical results reveal that swaps, forwards and options are frequently employed in handling interest rate risks and also foreign exchange hazards. This implies that foreign exchange, interest rate, future contracts, forward contracts, swaps, and commodity derivatives were essential techniques for handling the hazards facing corporations. In another study by Bartram, Brown, and Conrad (2011) the results disclosed powerful confirmation that derivatives usage is beneficial in lowering the overall and systematic hazards of companies. Consistent with their findings Boyer and Marin (2013) discovered that companies that extensively use forward-market derivatives to handle foreign exchange rates are much less susceptible to financial risks.

Extant studies revealed that risk management has received enormous popularity in recent years. In this case, therefore, numerous justifications have been theorized and empirically tested, but the results are unsatisfactory. Corporations in advanced and emerging economies face a multitude of hazards that call for hedging techniques to mitigate exposures, enabling companies to appreciate positive earnings and as such maximizing shareholder's worth (Butt, Nazir, Arshad, \& Shahzad, 2018). More ever, as a result of extreme competition, firms have widened the operations across the borders so as to take advantage of reasonable prices, economies of scale and gaining competitive advantage. However, changes in interest rates impact on the financing charges as well as on enterprise earnings. Similarly, most investors have become engaged in commodity trading and have invested in poorly diversified portfolios that could significantly increase commodity price and security risks. Prior scholarly study on ownership structure, which is a system for corporate governance, has been investigated in advanced economies, however, there is considerable need for further research in developing economies. Therefore, the aim of this research is to bridge the gap by exploring the impact of ownership structure on risk management among listed non-financial firms in NSE. 


\section{Literature Review \\ 2.1. Agency Theory}

Financial risk management theories by Bessembinder (1991); Smith and Stulz (1985) and agency theory by Jensen and Meckling (1976) posited that the application of hedging tools to alleviate exposures is essential in enhancing shareholder worth. They further argued that agency costs are indeed declining as managerial ownership increases whereas financial interests of corporate insiders and owners progressively converge. Fama and Jensen (1983) argued that contemporary institutions are differentiated by detaching leadership actions from controlling activities. The theory offers a wealthy theoretical basis for understanding structural systems and models from a principal-agent perspective. According to proponents of this theory (Jensen \& Meckling, 1976) executives who are agents formulates entities' decisions on behalf of owners who are principals of the firm. The agency problem arises when managers' interests are not aligned with the principals' welfares. Conflicts amongst the agents and shareholders may occur on issues like shareholder value, company value, investment choices, hedging decisions and compensation contracts (Jensen \& Smith, 2000). As part of this, the principal will delegate some decision-making authority to the agent. However, Subramaniam, McManus, and Zhang (2009) posit that agency theory tends to concentrate primarily on the motives of human behavior, in particular self-interest, and overlook other factors that may guide organizational decisions. The seminal paper of Jensen and Meckling (1976) defines the company as a nexus of contracts between the multiple factors of production resulting from the development of the agency theory in a production setup. The firm is not an ordinary person, but rather a legal entity, in which the conflicting objectives of the stakeholders are balanced within the framework of contractual obligations.

Risk management problems have been shown to shape management attitudes towards risk-taking and hedging (Smith \& Stulz, 1985). Agency theory offers powerful support to hedging as a remedy to the growing gap between management rewards and shareholder desires. The agency's risk management issue arises when the agent and the principal have varying thoughts on the magnitude of residual risk to be tolerated by the entity. In addition, Mallin and Melis (2012) affirmed that the information asymmetry in which the agent has access to more comprehensive information than the principal is yet another issue linked to the nexus of the contract and, furthermore, the agent can choose which information to provide or rescind from the principal. Thus, this information asymmetry triggers an imbalanced bond of dependence on the principal side. A more concrete result of the agency theory is that shareholders may be concerned about maintaining stake ownership by lowering corporate risk. However, agency theory also suggests that company policies can be swayed by the ownership composition in particular (Klimczak, 2005). Managers who hold shares in the firms they manage according to Tufano (1996) are more probable to hedge than managers who don't hold shares. Agency theory has indeed been applied to organizational hedging as a scheme to alleviate agency problems between shareholders, managers, and other stakeholders thereby enhancing governance mechanisms within an entity. For example, Allayannis, Lel, and Miller (2012) focused on monitoring the pressure on agents from owners and their impact on the value of derivatives. They discovered that the use of hedging tools enhances the worth of owners in a well-managed enterprises, in which directors have restricted powers to employ hedging instruments for speculation as well as personal-interest thus lowering uncertainty.

\subsection{Stakeholders' Theory}

Among the popularity of governance theories such as agency, resource dependency, and stewardship, stakeholder theory concur with the others that corporate governance consists of structures and procedures that guarantee how corporations are regulated and governed (Solomon, 2013). The theory was initially formulated by Freeman (1983) as a management tool and has since developed into a firm theory with a powerful explanatory ability. Stakeholder theory involved a theory of organizational management and business ethics that addresses morals and values as explicit central features of managing an organization (Phillips, 2003). The theory suggests that a company is not an entity that works exclusively for the benefit of the organization itself, but rather it should be able to reward its stakeholders, suggesting that the existence of the entity is strongly influenced by the stakeholders of the company. Contrary to agency theory, the stakeholder's stance is that executives are not always opportunistic and deserve adequate autonomy to shape corporate choices for the protection of stakeholders' benefits (Vilanova, 2007). The concept of stakeholders applies to anyone who has an impact or is obliged by the goals of a company whose support is essential to their success in ensuring that the objectives are of the kind that this attracts contribution (Hitt, Bierman, Shimizu, \& Kochhar, 2001). According to Gandini, Gennari, and Cassano (2014), they reasoned that to improve relations with stakeholders, it is necessary to have a voluntary formal publication of company's strategy about the management of risk in order to have a matured business values where transparency in the communication reflects objective and respectful to all stakeholders' expectations actions.

Various scholars postulated that corporate governance structures are in a state of transition owing to the internationalization of capital markets, leading to the convergence of the shareholder value-based approach to corporate governance and the stakeholder towards sustainable business systems (Ayuso, Rodríguez, GarcíaCastro, \& Ariño, 2014; Clarke, 2004). In this regard, the stakeholder is a collection of individuals who have had an impact on the company's activities in achieving its own objectives (Freeman, 1983). Any stakeholder is 
essential if their investment portfolios are vulnerable to danger from the organization activities (Crane \& Ruebottom, 2011; Jawahar \& McLaughlin, 2001). Firms engaged in hedging activities so as to moderate their uncertainty thus increasing their manager's utility (Dionne \& Triki, 2013; Marek, 2008). This is supported by the stakeholder theory which has been applied to corporate hedging as a managerial technique. As financial risk management activities result in a decline in exposures the value of the company rises and thus the worth of the shareholder will be maximized.

\subsection{The Link between Ownership Structure and Risk Management}

Following the contribution of Jensen and Meckling (1976) the structure of ownership relates to the breakdown of ownership rights held by insiders and investors without any kind of legitimate involvement in the stewardship of the company. This, therefore, implies that a small proportion of director ownership might not provide adequate incentive for directors to efficiently monitor the productivity of the administration on behalf of the owners. Excessive ownership by directors may, however, inevitably enshrine those directors who may maximize the individual welfare within the company at the price of the shareholder worth. According to Razali and Tahir (2011) ownership structure refers to the proportion of owners in relation to the percentage of the shareholding. According to Abraham and Cox (2007), ownership and governance which constitute the directors of the board may have an effect on management of risk through the application of hedging tools in mitigating future uncertainties. In addition, Owusu-Ansah (1998) verified that the structure of ownership and management of risk link is explained by agency theory since modern corporations are differentiated by the detachment of control from ownership. Jensen and Meckling (1976) observed that agency costs shrink as managerial ownership increases because the vested interests of insiders and shareholders progressively converged. Shareholders with significant holdings in a company according to Wright, Ferris, Sarin, and Awasthi (1996) models the nature of risk management that may affect the ability of an entity to compete and ultimately survive in a risky business atmosphere.

The ownership structure, which the main mechanism for corporate leadership, has an implication on the hedging behavior. The hedging propensity of managers as proposed (Lel, 2012) may be affected both by the corporate governance setting and by the ownership structure of enterprises (Tufano, 1996). In this regard, therefore, it implies that if protection is weak, executives who have been assigned to run the company in the long term best interest of the principal tend to use hedging tools for their own gain (Söhnke, Brown, \& Fehle, 2009). Moreover, Lel (2012) stated that businesses are much more inclined to be hedged when investors require greater transparency and better monitoring of firms ' activities in order to enhance the objective of value maximization. As stated by Osuoha, Samy, and Osuoha (2015) the ownership structure models the actions of the firm with regard to hedging operations. Misalignment of interest between external and internal block owners may have distinct incentives that can expose companies to financial hazards as Allayannis et al. (2012) posit. The use of derivatives, therefore, offers an appropriate way to reduce financial hazards and should be considered by executives. The consequences of derivatives for hedging as stated stimulate owners to raise the value of their equity.

Similarly, a sample of 262 French non-financial companies listed on the Paris Stock Exchange, Boubaker, Mefteh, and Shaikh (2010) established the impact of the ownership structure on the application of hedging instruments in the management of risks. The results revealed that the entity's ownership structure had a significant impact on the decisions of companies regarding the use of hedging tools. Additionally, Niclas, Holmén, and Pramborg (2006) assessed the extent of family-controlled entities on the utilization of hedging instruments by 427 Swedish non-financial companies listed on the Stockholm Stock Exchange from 1997 to 2001. The findings indicated that the biggest shareholder in the family and companies controlled by family owners was statistically significant and negatively influencing hedging operations. Another aspect of ownership structure includes managerial ownership and institutional ownership and it has been shown to have a significant association with hedging. Similarly, (Spanò, 2007) argued that executives with a greater shareholding proportion were favorably using derivatives to truncate risk in the best interests of investors.

The results of Al-Shboul and Alison (2009) which explored the magnitude of institutional and directors' ownership on the usage of hedging tools revealed that institutional ownership was positively linked to foreign exchange derivatives, however, the ownership of directors was not substantially related to the hedging in reducing foreign exchange risks. In contrast to the outcomes of Al-Shboul and Alison (2009); Wang and Fan (2011) discovered that outside block holders holding five percent or more of the common stock in a business are negatively linked to the utilization of hedging instruments in mitigating the risk as they prefer to minimize risk by diversifying their investment in a set of portfolios. Indeed, Whalley (2008) focused on the impact of executive ownership on hedge and showed evidence that managers make positive use of hedging derivatives in improving the intrinsic value of the share options while equity ownership might not encourage them to hedge using derivatives. Finally, Lel (2012) is among the few researchers who discovered no link between the block-holders ownership and management of risk. The author constructs a governance index that includes ownership structure, and investor protection rights in a worldwide context on companies from 30 nations. Results indicated that tight governance enables corporations to employ derivatives when faced with currency exposure, and when the firms are experiencing financial challenges. However, companies with weak 
governance use more currency derivatives to address weaknesses in undiversified portfolios and vise-versa when currency exposure is greater. Based on agency theory, stakeholder's theory and empirical reviews, the study hypothesis is formulated ass:

$H_{l:}$ Ownership structure has no significant effect on risk management.

\section{Research Methodology}

3.1. Research Design

The study used a positivist approach. Researchers who follow the positivism view believe that the natural scientist's philosophic standpoint emphasizes working with observable social reality to generate generalizations (Saunders \& Bezzina, 2015). The panel study design deemed to be appropriate as the study sought to establish the link between the predictor variable and the outcome variable over a number of years. The population targeted comprised of sixty-seven non-financial listed firms in Kenya Nairobi Securities Exchange. However, the exclusion-inclusion criterion was applied and a total of 17 financial firms including banks and Insurance companies were excluded from the study. Data for two firms was missing thus remaining with 41 non-financial listed firms that fit the requirements of the study from January 2010 to December 2017. The researcher's utilized panel data extracted from annual audited financial statements for firms included thus giving a total of 328 firm-year observations between the study periods. As pointed out by Hsiao (2014) panel data have the strength of accommodating more observations over a given time hence increasing the degree of freedom.

\subsection{Econometric Model}

The study employed logistic regression in establishing the link between ownership structure and risk management. The researchers collected data using a document analysis guide and thereafter descriptive statistics such as mean, standard deviation, maximum, minimum, skewness, and kurtosis were used in describing the data obtained from secondary sources. Inferential statistical analysis was performed to infer generalization and answer the hypothesis of the study. According to Hosmer, Lemeshow, and Sturdivant (2013) logistic regression analysis applies when the outcome variable is binary in nature. The logistic regression analysis model (transformation of probability log odds) was therefore applied in the study to test the formulated hypothesis. The following equation model was estimated by the researchers:

Where,

$$
\operatorname{logit}(y)=\beta_{0 i t}+\beta_{1} X_{1 i t}+\varepsilon_{i t}
$$

$\beta_{0 i t}=\quad$ The constant of the equation $X_{1 i t}=$ Ownership structure, $\beta_{1}=$ Coefficient of the estimate, $\varepsilon_{i t}=$ Error term and $\operatorname{logit}(y)=$ Likelihood of hedging using derivatives as a proxy of risk management.

\subsection{Measurement of Variables}

In tandem with Géczy, Minton, and Schrand (1997) dummy variable was used to measure risk management coded as 1 for hedger and o for non-hedgers. Ownership structure, on the other side, was determined as the proportion of shares retained by the top five biggest shareholders (Demsetz \& Villalonga, 2001). For control variables, natural logarithm was used to measure the size of the firm (Laeven, Ratnovski, \& Tong, 2014) also return on assets (ROA) was used to measure firm performance (Chen, Cheung, Stouraitis, \& Wong, 2005) while the age of the firm was determined as the number of years the entity has been in operation since incorporation (Yasuda, 2005).

\section{Data Analysis}

4.1. Descriptive Results

The statistical summary results are presented in Table 1 for risk management, ownership structure, firm size, firm performance, and firm age. The ownership structure which is the proportion of owners in relation to shareholding was at the (mean $=22.37$, Standard deviation $=18.89$, Skewness $=0.76$ and kurtosis $=2.49$ ). This, therefore, implied that the proportion of equities held the five top biggest shareholders over total shares on average was at the mean of 22 . However, the statistics result further revealed that the size of the firm ranges between 8 and 11 with a mean of 9.66 while (standard deviation $=0.61$, skewness $=0.07$ and kurtosis $=$ 3.16). More so, firm performance was at (mean ratio $=-0.03$, the standard deviation $=0.19$, skewness $=-1.96$ and kurtosis $=9.48$ ). This suggests that the majority of the firms were experiencing financial challenges. Finally, the results showed that firms have been in operation for the past 57 years ranging between 10 years and 108 years with a $($ mean $=57.66, \mathrm{SD}=36.75$, Skewness $=0.45$ and Kurtosis $=2.30$.

More findings revealed that risk management which is a practice of creating economic worth in the entity by utilizing hedging instruments to manage firm risk and hedge against uncertainties was at a $($ mean $=0.49$, standard deviation $=0.50$, skewness $=0.05$ and kurtosis $=1.00)$. The statistic findings indicate that 49 percent of companies have adopted hedging derivatives instruments as risk management tools, suggesting that there is comparatively low utilization of hedging tools among non-financial listed firms in Kenya. 
Table-1. Descriptive results of study variables.

\begin{tabular}{c|c|c|c|c|c|c|c}
\hline Stats & Obs & Min & Max & Mean & Sd & Skewness & Kurtosis \\
\hline Risk management & 326 & 0.00 & 1 & 0.49 & 0.50 & 0.05 & 1.00 \\
\hline Ownership structure & 327 & 0.00 & 69.7 & 22.37 & 18.89 & 0.76 & 2.49 \\
\hline Firm size & 327 & 8.25 & 11.28 & 9.66 & 0.61 & 0.07 & 3.16 \\
\hline Firm performance & 327 & -1.04 & 0.34 & -0.03 & 0.19 & -1.96 & 9.48 \\
\hline Firm age & 327 & 10.0 & 108 & 57.66 & 36.75 & 0.45 & 2.30 \\
\hline
\end{tabular}

4.2. Diagnostics Tests

The fisher-type unit-root test was employed in determining whether the unit root in the panel data exist. The outcomes of the test variables are shown in Table 2, which statistically showed that the p-values of all factors were less than $5 \%(\mathrm{p}<0.05)$ and therefore the study variables are reliable. The panel unit root test revealed that the variables were stationary hence the data was stationary.

\begin{tabular}{|c|c|c|c|c|}
\hline Variables & & & Statistic & p-value \\
\hline \multirow{4}{*}{ Risk management } & Inverse chi-squared(82) & $\mathrm{P}$ & 124.558 & 0.002 \\
\hline & Inverse normal & $\mathrm{Z}$ & -3.187 & 0.001 \\
\hline & Inverse logit $\mathrm{t}(144)$ & $\mathrm{L}^{*}$ & -4.324 & 0.000 \\
\hline & Modified inv. chi-squared & $\mathrm{Pm}$ & 3.323 & 0.000 \\
\hline \multirow[t]{4}{*}{ Ownership structure } & Inverse chi-squared(82) & $\mathrm{P}$ & 338.816 & 0.000 \\
\hline & Inverse normal & $\mathrm{Z}$ & -10.259 & 0.000 \\
\hline & Inverse logit $\mathrm{t}(209)$ & $\mathrm{L}^{*}$ & -13.657 & 0.000 \\
\hline & Modified inv. chi-squared & $\mathrm{Pm}$ & 20.054 & 0.000 \\
\hline \multirow[t]{4}{*}{ Firm size } & Inverse chi-squared(82) & $\mathrm{P}$ & 363.987 & 0.000 \\
\hline & Inverse normal & $\mathrm{Z}$ & -6.984 & 0.000 \\
\hline & Inverse logit $\mathrm{t}(204)$ & $\mathrm{L}^{*}$ & -13.462 & 0.000 \\
\hline & Modified inv. chi-squared & $\mathrm{Pm}$ & 22.020 & 0.000 \\
\hline \multirow[t]{4}{*}{ Firm performance } & Inverse chi-squared(64) & $\mathrm{P}$ & 270.290 & 0.000 \\
\hline & Inverse normal & $\mathrm{Z}$ & -7.144 & 0.000 \\
\hline & Inverse logit $\mathrm{t}(129)$ & $\mathrm{L}^{*}$ & -12.091 & 0.000 \\
\hline & Modified inv. chi-squared & $\mathrm{Pm}$ & 18.234 & 0.000 \\
\hline \multirow[t]{4}{*}{ Firm age } & Inverse chi-squared(82) & $\mathrm{P}$ & 2816.830 & 0.000 \\
\hline & Inverse normal & $\mathrm{Z}$ & -49.276 & 0.000 \\
\hline & Inverse logit $\mathrm{t}(209)$ & $\mathrm{L}^{*}$ & -121.016 & 0.000 \\
\hline & Modified inv. chi-squared & $\mathrm{Pm}$ & 213.554 & 0.000 \\
\hline
\end{tabular}

The multicollinearity results from the study are highlighted in Table 3 which revealed that the maximum Variance Inflation Factor (VIF) was at 1.12 and the minimum VIF is at 1.07 with an average mean of 1.25. The average VIF was less than 10, the threshold that is used as a thumb rule to indicate the presence of multicollinearity problems. The findings were within normal bounds and thus support the absence of multicollinearity issues in the research model $\mathrm{VIF}<10$.

\begin{tabular}{l|c|c}
\multicolumn{3}{c}{ Table-3. Multicollinearity. } \\
\hline Variable & VIF & $\mathbf{1 / V I F}$ \\
\hline Firm age & 1.12 & 0.889 \\
\hline Firm performance & 1.12 & 0.895 \\
\hline Ownership structure & 1.08 & 0.925 \\
\hline Firm size & 1.07 & 0.934 \\
\hline Mean VIF & 1.25 & \\
\hline
\end{tabular}

\subsection{Hypothesis Testing}

Findings from Table 4 showed that the ownership structure explained $21.27 \%$ of risk management in nonfinancial listed firms (Pseudo $\mathrm{R}^{2}=21.27$ ). The results further disclosed that the ownership structure had a significant and positive effect $(\beta=0.297, \mathrm{p}<0.05)$ on risk management. It may predict that the structure of shareholders in lieu of shareholding is more probable to participate in hedging operations due to an increase in the intrinsic value of their equities, which eventually contributes to better company results and thus maximizing the wealth. This means that the structure of shareholders, in lieu of shareholding influences the decisions of companies on hedging operations. 
On the control variables, the results show that firm size had a positive and insignificant $(\beta=1.682, p>$ 0.05) influence on risk management. Due to statistically insignificant and positive values it, therefore, implies that firm size had no influence on the outcome variable. The results are in contrast to other studies who found positive and significant results (Bashir, Sultan, \& Jghef, 2013; Fok, Carroll, \& Chiou, 1997). The firm performance had a beta coefficient of 0.655 and a standard error of .118 with a p-value less than 0.05 at Prob $>$ chi $2=0.000$. It postulates that successful entities in relation to profitability incline the significance of using hedging tools to manage corporate risks. The findings are in line with the results of (Butt et al., 2018); Carter, Rogers, and Simkins (2006) but George and Weston (2001) results are contrary to their findings. The company's age which is the last control variable had a statistically negative and insignificant impact $(\beta=-$ $0.248, p>0.05)$ on risk management. Thus, centered on statistical results, firm age was not statistically significant and therefore did not affect corporate risk management.

The Hosmer-Lemeshow of goodness predicts how suitable the logistic model defines the reaction variable. The Hosmer-Lemeshow is a frequently used test for evaluating the logistic fitness and permits for any number of explanatory variables, which may be continuous or categorical. The Hosmer-Lemeshow goodness of fit enables in determining whether the model is fitted properly. The model fitness involves probing how close the predicted values are to the observed values (Bewick, Cheek, \& Ball, 2005) stated neither over fitting nor under fitting should not occur in the model. The goodness of fit tests produces a $p$-value and if it's less than $5 \%(p<0.05)$, it is rejected and it can be concluded that the model is not fit. However, if the $p$-value is greater than $5 \%(p>0.05)$, then the model passes the test and thus it is said to be fit. The Hosmer- Lemeshow test yielded Pearson chi $^{2}$ of 111.57 with the probability of 0.6964 which is more than $5 \%(p>.05)$ suggesting that the Hosmer-Lemeshow model is fit to be used.

\begin{tabular}{|c|c|c|c|c|c|c|}
\hline \multicolumn{3}{|l|}{$\begin{array}{l}\text { Logistic regression } \\
\text { Log likelihood }=-103.64059\end{array}$} & \multicolumn{2}{|c|}{$\begin{array}{l}\text { Number of obs } \\
\text { LR chi2(4) } \\
\text { Prob > chi2 } \\
\text { Pseudo R2 }\end{array}$} & $\begin{array}{l}= \\
= \\
= \\
=\end{array}$ & \multirow[t]{2}{*}{$\begin{array}{l}326 \\
55.99 \\
0 \\
0.2127 \\
\text { Interval] }\end{array}$} \\
\hline Risk management & Coef. & Std. Err. & $\mathbf{Z}$ & $\mathbf{P}>\mathbf{z}$ & [95\% Conf. & \\
\hline Ownership structure & 0.297 & 0.126 & 2.370 & 0.018 & 0.051 & 0.544 \\
\hline Firm size & 1.682 & 2.178 & 0.770 & 0.440 & -2.586 & 5.951 \\
\hline Firm performance & 0.655 & 0.118 & 5.560 & 0.000 & 0.424 & 0.886 \\
\hline Firm age & -0.248 & 0.183 & -1.360 & 0.175 & -0.606 & 0.110 \\
\hline cons & -1.431 & 5.020 & -0.290 & 0.776 & -11.270 & 8.408 \\
\hline \multicolumn{7}{|c|}{ Hosmer-Lemeshow goodness of fit test } \\
\hline \multicolumn{3}{|c|}{ Number of observations } & & & & \\
\hline \multicolumn{2}{|l|}{ Number of covariate patterns } & 326 & & & & \\
\hline \multicolumn{2}{|l|}{ Pearson chi2(120) } & 111.57 & & & & \\
\hline Prob > chi2 & $=$ & 0.6964 & & & & \\
\hline
\end{tabular}

\section{Discussion and Recommendations}

The study empirically estimates the likelihood of utilizing derivative hedging tools to mitigate firm exposures on the link between ownership structure and risk management. Prior scholars have investigated the determinants of derivatives (Dionne \& Triki, 2013; Smith \& Stulz, 1985; Söhnke et al., 2009; Wang \& Fan, 2011) and few studies on structure of ownership and derivative utilization (Boubaker et al., 2010; Butt et al., 2018; Niclas et al., 2006) have been studied in advanced markets. This research sheds new light on the assessment of ownership structure and risk management by employing derivative tools as a measure of risk management among non-financial publicly traded companies in the Kenyan setting. The empirical results revealed that ownership structure positively and significantly impacts on risk management. This means that the proportion of owners in connection to the shareholder reflects the policies of the companies regarding hedging operations and thus they are more probable to be involved in hedging operations due to an upturn in the intrinsic value of their shares held, which eventually leads to enhanced company results and thus achieving their wealth maximization. The explanation is in conformity with the results of Wright et al. (1996) which have shown that owners with substantial stakes in business can influence the kind of risk management that may impact the capacity of an entity to compete and ultimately its survival.

In line with the study findings, Boubaker et al. (2010) discovered that the ownership structure of entities had a significant effect on enterprise decisions over the use of derivatives._Further support for the results of the research is provided by Ifeanyichukwu (2013) who observed that the ownership structure affects the choices of companies on hedging actions. The results are also in conformity to the findings of Whalley (2008) who provided evidence executive ownership positively and significantly enhances the value of equities by properly utilizing hedging tools. This implies that risk mitigation using derivatives is an essential factor in corporate governance as it encourages managers to employ hedging practices along with investment, financial, 
and operational strategies for the best interest of the company and the shareholders in general. On the other side (Wang \& Fan, 2011) discovered that external block holders holding five percent or more of the ordinary shares in a business are negatively linked to the use of derivatives in mitigating hazards as they opt to minimize the risks by diversifying their portfolio in more than one entity. The results of the research are also in contrast to the statistical outcomes of Allayannis et al. (2012) and Hagelin, Holmén, Knopf, and Pramborg (2007) which discovered that the top five and biggest shareholders of the company are less inclined to depend on derivative instruments for hedging reasons due to their concern.

Agency theory provides strong support for hedging as a response to the disparity between managerial incentives and shareholder interests thus, in the context of risk management, a firm's ownership structure influence how firms use derivatives contracts in mitigating exposures. Risk management theory by Bessembinder (1991); Smith and Stulz (1985) posited that the use of derivatives tools have been essential in enhancing shareholder value by lowering corporate risk. Firm's hedge to reduce their uncertainty and to increase their manager's utility. This is backed by the stakeholder theory that has been applied in hedging as a corporate managerial tool (Freeman, 1983). Since risk management operations result in a reduction in exposures and uncertainty, the value of the enterprise increases and thus shareholders worth is maximized. The study concludes that the composition of owners in terms of shareholding is more likely to engage in hedging activities because of increasing the value of their equities which ultimately leads to better firm performance and thus achieving their wealth maximization. This implies that the composition of owners in terms of shareholding shapes firms' decisions regarding hedging activities.

The study, therefore, contributes to the agency theory and the stakeholder theory as the utilization of financial derivative instruments on ownership structure mitigate exposures and thus enhancing the net worth of the owners. The present research also provides an excellent contribution to the available literature on corporate governance and also a valuable addition to the research of derivatives instruments as tools of risk management. The research provides policy guidelines for Kenyan companies listed in the securities that aim to make optimal utilization of financial derivatives instruments for reducing foreign exchange rates, commodity price volatility, interest rates equity price exposures. It also recommends that policymakers must develop a well-established derivative market in Kenya which is still at the infancy stage so as to create awareness of derivative utilization in enhancing shareholders' worth. Future research should concentrate on the link between ownership structure and firm hedging in the case of financial institutions.

\section{References}

Aaron, P. L. (1995). 1995 derivatives practices and instruments survey. Financial Management, 24(2), 115-125. Available at: https://doi.org/10.2307/3665539.

Abraham, S., \& Cox, P. (2007). Analysing the determinants of narrative risk information in UK FTSE 100 annual reports. The British Accounting Review, 39(3), 227-248. Available at: https://doi.org/10.1016/j.bar.2007.06.002.

Al-Shboul, M., \& Alison, S. (2009). The effects of the use of corporate derivatives on the foreign exchange rate exposure. Journal of Accounting, Business \& Management, 16(1), 72-92.

Allayannis, G., Lel, U., \& Miller, D. P. (2012). The use of foreign currency derivatives, corporate governance, and firm value around the world. Journal of International Economics, 87(1), 65-79. Available at: https://doi.org/10.1016/j.jinteco.2011.12.003.

Ayuso, S., Rodríguez, M. A., García-Castro, R., \& Ariño, M. A. (2014). Maximizing stakeholders' interests: An empirical analysis of the stakeholder approach to corporate governance. Business $\mathcal{E}^{2}$ Society, 53(3), 414-439. Available at: https://doi.org/10.1177/0007650311433122.

Bartram, S. M., Brown, G. W., \& Conrad, J. (2011). The effects of derivatives on firm risk and value. Journal of Financial and Quantitative Analysis, 46(4), 967-999. Available at: https://doi.org/10.1017/s0022109011000275.

Bashir, H., Sultan, K., \& Jghef, O. K. (2013). Impact of derivatives usage on firm value: Evidence from non financial firms of Pakistan. Journal of Management Research, 5(4), 108-127.

Bessembinder, H. (1991). Forward contracts and firm value: Investment incentive and contracting effects. Journal of Financial and Quantitative Analysis, 26(4), 519-532. Available at: https://doi.org/10.2307/2331409.

Bewick, V., Cheek, L., \& Ball, J. (2005). Statistics review 14: Logistic regression. Critical Care, 9(1), 112-118.

Boubaker, S., Mefteh, S., \& Shaikh, J. M. (2010). Does ownership structure matter in explaining derivatives' use policy in French listed firms. International Journal of Managerial and Financial Accounting, 2(2), 196-212. Available at: https://doi.org/10.1504/ijmfa.2010.033291.

Boyer, M. M., \& Marin, M. (2013). Financial distress risk and the hedging of foreign currency exposure. Quarterly Journal of Finance, 3(01), 1-36. Available at: https://doi.org/10.1142/s201013921350002x.

Butt, A. A., Nazir, M. S., Arshad, H., \& Shahzad, A. (2018). Corporate derivatives and ownership concentration: Empirical evidence of non-financial firms listed on Pakistan stock exchange. Journal of Risk and Financial Management, 11(3), 1-15. Available at: https://doi.org/10.3390/jrfm 11030033.

Carter, D. A., Rogers, D. A., \& Simkins, B. J. (2006). Does hedging affect firm value? Evidence from the US airline industry. Financial Management, 35(1), 53-86. Available at: https://doi.org/10.1111/j.1755-053x.2006.tb00131.x.

Chen, Z., Cheung, Y.-L., Stouraitis, A., \& Wong, A. W. (2005). Ownership concentration, firm performance, and dividend policy in Hong Kong. Pacific-Basin Finance Journal, 13(4), 431-449. Available at: https://doi.org/10.1016/j.pacfin.2004.12.001. 
Clarke, T. (2004). Cycles of crisis and regulation: The enduring agency and stewardship problems of corporate governance. Corporate Governance: An International Review, 12(2), 153-161. Available at: https://doi.org/10.1111/j.14678683.2004.00354.x.

Crane, A., \& Ruebottom, T. (2011). Stakeholder theory and social identity: Rethinking stakeholder identification. Journal of Business Ethics, 102(1), 77-87. Available at: https://doi.org/10.1007/s 10551-011-1191-4.

Crouhy, M., Galai, D., \& Mark, R. (2006). Risk capital attribution and risk-adjusted performance measurement. In Risk Management (pp. 433-454): Academic Press.

Cumming, C. M., \& Hirtle, B. J. (2001). The challenges of risk management in diversified financial companies. Federal Reserve Bank of New York Economic Policy Review, 7(1), 1.

Demsetz, H., \& Villalonga, B. (2001). Ownership structure and corporate performance. Journal of Corporate Finance, 7(3), 209-233.

Dionne, G., \& Triki, T. (2013). On risk management determinants: What really matters? The European Journal of Finance, 19(2), 145-164. Available at: https://doi.org/10.1080/1351847x.2012.664156.

Fama, E. F., \& Jensen, M. C. (1983). Separation of ownership and control. The Journal of Law and Economics, 26(2), 301325.

Fok, R. C., Carroll, C., \& Chiou, M. C. (1997). Determinants of corporate hedging and derivatives: A revisit. Journal of Economics and Business, 49(6), 569-585.

Freeman, R. E. (1983). Strategic management: A stakeholder approach. Advances in Strategic Management, 1(1), 31-60.

Gandini, G., Gennari, F., \& Cassano, R. (2014). Global responsibility and strategic risk management. Journal of Business and Management Applied Economics, 3, 1-17.

Géczy, C., Minton, B. A., \& Schrand, C. (1997). Why firms use currency derivatives. The Journal of Finance, 52(4), 13231354. Available at: https://doi.org/10.1111/j.1540-6261.1997.tbo1112.x.

George, A., \& Weston, J. P. (2001). The use of foreign currency derivatives and firm market value. The Review of Financial Studies, 14(1), 243-276. Available at: https://doi.org/10.1093/rfs/14.1.243.

Grant, K., \& Marshall, A. P. (1997). Large UK companies and derivatives. European Financial Management, 3(2), 191-208. Available at: https://doi.org/10.1111/1468-036x.00039

Hagelin, N., Holmén, M., Knopf, J. D., \& Pramborg, B. (2007). Managerial stock options and the hedging premium. European Financial Management, 13(4), 72 1-741. Available at: https://doi.org/10.1111/j.1468-036x.2007.00380.x.

Hentschel, L., \& Kothari, S. P. (2001). Are corporations reducing or taking risks with derivatives? Journal of Financial and Quantitative Analysis, 36(1), 93-1 18. Available at: https://doi.org/10.2307/2676199.

Hitt, M. A., Bierman, L., Shimizu, K., \& Kochhar, R. (2001). Direct and moderating effects of human capital on strategy and performance in professional service firms: A resource-based perspective. Academy of Management Journal, 44(1), 13-28. Available at: https://doi.org/10.5465/3069334.

Hosmer, J. D. W., Lemeshow, S., \& Sturdivant, R. X. (2013). Applied logistic regression (Vol. 398). John Wiley \& Sons.

Hsiao, C. (2014). Analysis of panel data (No. 54): Cambridge University Press.

Hull, J. (2012). Risk management and financial institutions, + Web Site (Vol. 733). John Wiley \& Sons.

Ifeanyichukwu, O. J. (2013). Financial engineering, corporate goverance and Nigeria economic development. Journal of Financial Risk Management, 2(04), 61-66.

Jawahar, I., \& McLaughlin, G. L. (2001). Toward a descriptive stakeholder theory: An organizational life cycle approach. Academy of Management Review, 26(3), 397-414. Available at: https://doi.org/10.5465/amr.2001.4845803.

Jensen, M. C., \& Meckling, W. H. (1976). Theory of the firm: Managerial behavior, agency costs and ownership structure. Journal of Financial Economics, 3(4), 305-360. Available at: https://doi.org/10.1016/0304-405x(76)90026-x.

Jensen, M. C., \& Smith, C. W. (2000). Stockholder, manager, and creditor interests: Applications of agency theory. Theory of the Firm, 1(1), 1-45. Available at: http://doi.org/10.2139/ssrn.173461.

Klimczak, K. (2005). Corporate risk management from stakeholders' perspective. MPRA Paper No. 4242, 1-12.

Laeven, M. L., Ratnovski, L., \& Tong, H. (2014). Bank size and systemic risk (No. 14). International Monetary Fund.

Lel, U. (2012). Currency hedging and corporate governance: A cross-country analysis. Journal of Corporate Finance, 18(2), 221-237. Available at: https://doi.org/10.1016/j.jcorpfin.2011.12.002.

Leung, S., \& Horwitz, B. (2010). Corporate governance and firm value during a financial crisis. Review of Quantitative Finance and Accounting, 34(4), 459-481. Available at: https://doi.org/10.1007/s11156-009-0141-z.

Mallin, C., \& Melis, A. (2012). Shareholder rights, shareholder voting, and corporate performance. Journal of Management E Governance, 16(2), 171-176. Available at: https://doi.org/10.1007/s10997-010-9138-1.

Marek, K. K. (2008). Corporate hedging and risk management theory: Evidence from Polish listed companies. The Journal of Risk Finance, 9(1), 20-39. Available at: https://doi.org/10.1108/15265940810842393.

Mittal, S., Khakhar, D., \& Mittal, D. (2015). Hedging-an effective tool for risk management. International Multidisciplinary Research Journal, 2(1), 1-8.

Modigliani, F., \& Miller, M. H. (1958). The cost of capital, corporation finance and the theory of investment. The American Economic Review, 48(3), 261-297.

Niclas, H., Holmén, M., \& Pramborg, B. (2006). Family ownership, dual-class shares, and risk management. Global Finance Journal, 16(3), 283-301. Available at: https://doi.org/10.1016/j.gfj.2006.01.002.

Osuoha, J., Samy, M., \& Osuoha, O. (2015). The impact of corporate governance on derivatives usage, empirical evidence from African non-financial firms. British Journal of Economics, Management \& Trade, 8(1), 19-31. Available at: https://doi.org/10.9734/bjemt/2015/15580.

Owusu-Ansah, S. (1998). The impact of corporate attribites on the extent of mandatory disclosure and reporting by listed companies in Zimbabwe. The International Journal of Accounting, 33(5), 605-631. Available at: https://doi.org/10.1016/s0020-7063(98)90015-2.

Paunović, J. (2014). Options, Greeks, and risk management. Singidunum Journal of Applied Sciences, 11(1), 74-83. Available at: https://doi.org/10.5937/sjas 11-5820. 
Phillips, R. (2003). Stakeholder theory and organizational ethics: Berrett-Koehler Publishers.

Rao, G. S. (2012). Derivatives in risk management. International Journal of Advanced Research in Management and Social Sciences, $1(4), 55-60$.

Razali, A. R., \& Tahir, I. M. (2011). Review of the Literature on Enterprise Risk Management. Business Management Dynamics, 1(5), 8-16.

Saunders, M. N., \& Bezzina, F. (2015). Reflections on conceptions of research methodology among management academics. European Management Journal, 33(5), 297-304.

Smith, C. W., \& Stulz, R. M. (1985). The determinants of firms' hedging policies. Journal of Financial and Quantitative Analysis, 20(4), 391-405.

Söhnke, B. M., Brown, G. W., \& Fehle, F. R. (2009). International evidence on financial derivatives usage. Financial Management, 38(1), 185-206. Available at: https://doi.org/10.1111/j.1755-053x.2009.01033.x.

Solomon, J. (2013). Corporate governance and accountability (4th ed.): John Wiley \& Sons Inc.

Spanò, M. (2007). Managerial ownership and corporate hedging. Journal of Business Finance \& Accounting, 34(7-8), 12451280. Available at: https://doi.org/10.1111/j.1468-5957.2007.02024.x.

Stulz, R. M. (1996). Rethinking risk management. Journal of Applied Corporate Finance, 9(3), 8-25.

Subramaniam, N., McManus, L., \& Zhang, J. (2009). Corporate governance, firm characteristics and risk management committee formation in Australian companies. Managerial Auditing Journal, 24(4), 316-339. Available at: https://doi.org/10.1108/02686900910948170.

Tufano, P. (1996). Who manages risk? An empirical examination of risk management practices in the gold mining industry. The Journal of Finance, 51(4), 1097-1137. Available at: https://doi.org/10.1111/j.15406261.1996.tb04064.x.

Vilanova, L. (2007). Neither shareholder nor stakeholder management: What happens when firms are run for their shortterm salient stakeholder? European Management Journal, 25(2), 146-162. Available at: https://doi.org/10.1016/j.emj.2007.01.002.

Wang, X., \& Fan, L. (2011). The determinants of corporate hedging policies. International Journal of Business and Social Science, 2(6), 29-38.

Whalley, A. E. (2008). Effect of executive share ownership and private hedging on executive stock option exercise and values. Warwick Business School. Retrieved: http://www. warwick. ac. $\mathrm{uk} / \mathrm{fac} / \mathrm{soc} / \mathrm{wbs} /$ subjects/finance/faculty 1/elizabeth_whalley/esohedging. pdf [Accessed 26 January 2018].

Wright, P., Ferris, S. P., Sarin, A., \& Awasthi, V. (1996). Impact of corporate insider, blockholder, and institutional equity ownership on firm risk taking. Academy of Management journal, 39(2), 441-458. Available at: https://doi.org/10.5465/256787.

Yasuda, T. (2005). Firm growth, size, age and behavior in Japanese manufacturing. Small Business Economics, 24(1), 1-15. Available at: https://doi.org/10.1007/s11187-005-7568-y 